\title{
The Etiology of Hospital Infections in the Intensive Care Unit of a Reference Hospital in Southern Mozambique
}

Filipe António Mahaluça ${ }^{1,2^{\star}}$, Sabiha Essack ${ }^{3}$ and Jahit Sacarlal ${ }^{4}$

${ }^{1}$ Higher Institute of Health Sciences (ISCISA), Mozambique

${ }^{2}$ Higher Institute of Accounting and Audit of Mozambique (ISCAM), Mozambique

${ }^{3}$ University of KwaZulu-Natal, South Africa

${ }^{4}$ Faculty of Medicine-Eduardo Mondlane University, Mozambique

${ }^{*}$ Corresponding author: Filipe António Mahaluça, Higher Institute of Health Sciences (ISCISA) and Higher Institute of Accounting and Audit of Mozambique (ISCAM), Mozambique, Tel: +258-848407234,+21496083; E-mail: mahaluca@gmail.com

Received date: Oct 07, 2018; Accepted date: Oct 22, 2018; Published date: Oct 31, 2018

Copyright: ( 2018 Mahaluça FA, et al. This is an open-access article distributed under the terms of the Creative Commons Attribution License, which permits unrestricted use, distribution, and reproduction in any medium, provided the original author and source are credited.

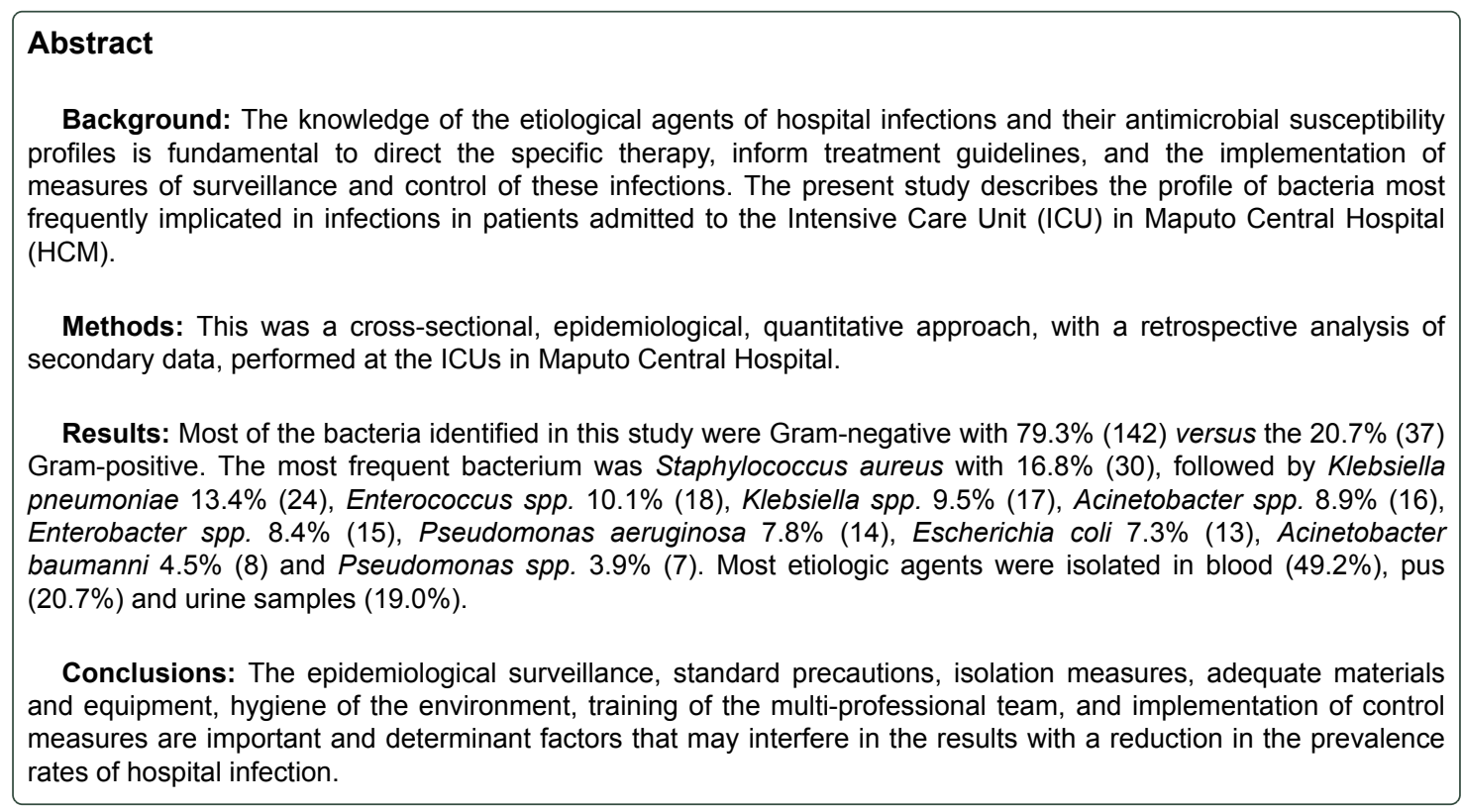

Keywords: Hospital infection; Intensive care; Bacteria; Sample type; Mozambique

\section{Introduction}

Health-care-related infections represent a major problem for patient safety and quality of life, and their impact may result in death, prolonged hospitalization, long-term disability, a large financial burden on health facilities, and high costs for patients and their relatives [1].

Intensive Care Unit (ICU) patients, although comprising a small subset of hospitalized patients, representing only $5 \%$ to $10 \%$ of the sum, present an average risk of infection 5 to 10 times higher than other patients and mortality rates range from 10 to $80 \%$, according to the profile of the hospitalized patient [2].

The main causes of infections are the clinical conditions of the patient, underlying diseases, high numbers of invasive procedures, failures in infection control measures, and prevention of noninvasive infections (urinary, pneumonias and surgical wounds) as well as invasive methods of mechanical ventilation and intravascular catheters.
Critically ill patients are more vulnerable because they are in a susceptible environment and have low immunity. These factors may contribute to high infection rates and high hospital mortality in ICUs. The most prevalent infections are of the respiratory tract, urinary tract, bloodstream, surgical site and pneumonia associated with mechanical ventilation [3]. The etiological agents most commonly found in hospital infections are Klebsiella pneumoniae, Staphylococcus aureus, Pseudomonas aeruginosa, Acinetobacter spp., Escherichia coli, Enterobacter spp. and Candida spp. [4]. Consequently, nosocomial infections influence longer hospitalization time, higher hospital costs and increased hospital deaths [5].

More than $70 \%$ of critically ill patients hospitalized in the ICUs receive some antimicrobial treatment during their stay. In addition, infections play an important role in morbidity and mortality within the units, and the prevalence of pathogen infections whose treatment is increasingly complex has steadily increased over the past few years [6,7].

The knowledge of the etiological agents of hospital infections and their antimicrobial susceptibility profiles is fundamental to direct the specific therapy, inform treatment guidelines, as well as the 
Citation: Mahaluça FA, Essack S, Sacarlal J (2018) The Etiology of Hospital Infections in the Intensive Care Unit of a Reference Hospital in

Page 2 of 5

implementation of measures of surveillance and control of these infections.

Considering these factor, the present study describes the profile of bacteria most frequent implicated in infections in patients admitted to the ICUs in Maputo Central Hospital (HCM).

\section{Materials and Methods}

This was a retrospective, descriptive cross-sectional, epidemiological, quantitative study of data obtained from the HCM Microbiology Laboratory. The study was carried out in the Pediatrics ICU, Medicine ICU and Surgical ICU at HCM from January to December 2017, with the data from latter consolidated. HCM is a quaternary public and teaching hospital with about 1463 beds, provides 4 Intensive Care Services: the Emergency ICU with 16 beds, the Medicine ICU with 6 beds, the Pediatrics ICU with 16 beds and the Surgical ICU with 12 beds. During the study period, 1913 patients of all ages and both sexes were admitted to HCM ICUs, including 1129 in the Pediatrics ICU, 355 in the Medicine ICU and 429 in the Surgical ICU.

Data on the profile of etiological agents was extracted from the WHONET electronic database of the HCM Microbiology Laboratory, which was set up at the end of October 2009 in order to monitor antimicrobial resistance in bacteria isolated from routine clinical samples. The database contains information on the specimens taken, patient details, growth or non-growth of infectious agents, the bacteria isolated, antibiotic sensitivity, as well as data from the patient justifying examination [8].

A descriptive statistical analysis was performed using graphs and frequency tables to understand the behavior of the variables under study. Data analysis was done with the Statistical Package for Social Sciences (SPSS) version 20 and BioEst version 5.2. The Z-test or Standardized Score was used for the comparison of proportions and the P-value of less than 0.05 was considered significant.

Before conducting data analysis, a request for authorization of the research was submitted to the HCM Scientific and Pedagogical Department under reference number 321/024/DCIEFHCM/18. After authorization of the research request, the project was submitted to the ISCISA Institutional Health Bioethics Committee and approved under reference number TFCMCSFM05/18.

The study complied with the 2013 Helsinki Declaration on health research standards.

\section{Results}

Of the 524 specimens taken, 179 were positive for bacteriological growth, of which 127 (70.9\%) were from the Pediatrics ICU, 51 (29.1\%) from the Adults ICU. Of the positive samples, 88 (49.2\%) were of blood, 37 (20.7\%) pus, 34 (19.0\%) urine, 7 (4.5\%) catheter tip, 4 (2.8\%) sputum, $32(1.1 \%)$ pharyngeal exudate and faeces respectively. There was no positive bacteriological examination for urethral and vaginal secretions (Table 1).

According to Table 2, most of the microorganisms identified in this study were Gram-negative with $79.3 \%$ (142) against the $20.7 \%$ (37) Gram-positive. The most frequent bacterium was Staphylococcus Aureus with $16.8 \%$ (30), followed by Klebsiella pneumoniae with 13.4\% (24), Enterococcus spp. 10.1\% (18), Klebsiella spp. 9.5\% (17), Acinetobacter spp. $8.9 \%$ (16), Enterobacter spp. $8.4 \% \quad$ (15),
Pseudomonas aeruginosa 7.8\% (14), Escherichia coli 7.3\% (13), Acinetobacter baumanni 4.5\% (8) and Pseudomonas spp. 3.9\% (7).

\begin{tabular}{|l|c|c|c|c|c|c|}
\hline \multirow{2}{*}{ Sample Type } & \multicolumn{5}{c}{ Type of ICU } \\
\cline { 2 - 7 } & \multicolumn{2}{|c|}{ Pediatrics } & \multicolumn{2}{c|}{ Adults } & \multicolumn{2}{c|}{ Sum } \\
\cline { 2 - 7 } & $\mathbf{n}$ & $\%$ & $\mathbf{n}$ & $\%$ & $\mathbf{n}$ & $\%$ \\
\hline Blood & 68 & 77.3 & 20 & 22.7 & 88 & 49.2 \\
\hline Urine & 16 & 47.1 & 18 & 52.9 & 34 & 19 \\
\hline CSF & 3 & 100 & 0 & 0 & 3 & 1.7 \\
\hline Pus & 34 & 91.9 & 3 & 8.1 & 37 & 20.7 \\
\hline Catheter tip & 4 & 50 & 4 & 50 & 8 & 4.5 \\
\hline Faeces & 2 & 100 & 0 & 0 & 2 & 1.1 \\
\hline Expectoration & 0 & 0 & 5 & 100 & 5 & 2.8 \\
\hline Pharyngeal Exudate & 0 & 0 & 2 & 100 & 2 & 1.1 \\
\hline Sum & 127 & 70.9 & 52 & 29.1 & 179 & 100 \\
\hline
\end{tabular}

Table 1: Positive culture distribution in samples of pediatric and adult ICU patients from HCM in the year 2017.

\begin{tabular}{|l|c|c|c|c|c|c|}
\hline \multirow{2}{*}{ Microorganisms } & \multicolumn{5}{|c|}{ Type of ICU } \\
\cline { 2 - 7 } & \multicolumn{2}{|c|}{ Pediatrics } & \multicolumn{2}{|c|}{ Adults } & \multicolumn{2}{c|}{ Sum } \\
\cline { 2 - 7 } & $\mathbf{n}$ & $\%$ & $\mathbf{n}$ & $\%$ & $\mathbf{n}$ & $\%$ \\
\hline A.paumanni & 6 & 4.7 & 2 & 3.8 & 8 & 4.5 \\
\hline Acinetobacter spp. & 14 & 11 & 2 & 3.8 & 16 & 8.9 \\
\hline Citrobacter spp. & 6 & 4.7 & 0 & 0 & 6 & 3.4 \\
\hline E.coli & 7 & 5.5 & 6 & 11.5 & 13 & 7.3 \\
\hline Enterobacter spp. & 10 & 7.9 & 5 & 9.6 & 15 & 8.4 \\
\hline Enterococcus spp. & 7 & 5.5 & 11 & 21.2 & 18 & 10.1 \\
\hline K.pneumoniae & 20 & 15.7 & 4 & 7.7 & 24 & 13.4 \\
\hline Klebsiella spp. & 5 & 3.9 & 12 & 23.1 & 17 & 9.5 \\
\hline P.aeruginosa & 13 & 10.2 & 1 & 1.9 & 14 & 7.8 \\
\hline Pseudomonas spp. & 5 & 3.9 & 2 & 3.8 & 7 & 3.9 \\
\hline S.aureus & 24 & 18.9 & 6 & 11.5 & 30 & 16.8 \\
\hline $\begin{array}{l}\text { Staphylococcus } \\
\text { spp. }\end{array}$ & 4 & 3.1 & 0 & 0 & 4 & 2.2 \\
\hline $\begin{array}{l}\text { Stenotrophomona } \\
\text { spp. }\end{array}$ & 3 & 2.4 & 1 & 1.9 & 4 & 2.2 \\
\hline Streptococcus spp. & 3 & 2.4 & 0 & 0 & 3 & 1.7 \\
\hline Sum & 127 & 70.9 & 52 & 29.1 & 179 & 100 \\
\hline
\end{tabular}

Table 2: Frequency of etiological agents associated with infections in pediatric and adult ICUs patients at HCM in 2017. 
Citation: Mahaluça FA, Essack S, Sacarlal J (2018) The Etiology of Hospital Infections in the Intensive Care Unit of a Reference Hospital in

Page 3 of 5

In the Pediatrics ICU, the most prevalent microorganism $(>10 \%)$ was Staphylococcus Aureus with 18.9\%, Klebsiella pneumoniae (15.7\%) and Acinetobacter spp. (11\%). The species of Stenotrophomona spp. and Streptococcus spp. were the least predominant with only $2.4 \%$ each.

\begin{tabular}{|l|c|c|c|c|c|c|c|c|}
\hline \multirow{2}{*}{ Microorganisms } & \multicolumn{7}{|c|}{ Type of ICU } \\
\cline { 2 - 9 } & \multicolumn{2}{|c|}{ Pediatrics } & \multicolumn{2}{|c|}{ Adults } & \multicolumn{2}{c|}{ Sum } & \multicolumn{2}{|c|}{ Z Test } \\
\cline { 2 - 10 } & $\mathbf{n}$ & $\%$ & $\mathbf{n}$ & $\%$ & $\mathbf{n}$ & $\%$ & $\mathbf{Z}$ & P-value \\
\hline A.baumanni & 3 & 4.4 & 2 & 10 & 5 & 5.7 & 0.949 & 0.3426 \\
\hline $\begin{array}{l}\text { Acinetobacter } \\
\text { spp. }\end{array}$ & 7 & 10.3 & 0 & 0 & 7 & 8 & & \\
\hline $\begin{array}{l}\text { Citrobacter spp. } \\
\text { E.coli }\end{array}$ & 4 & 5.9 & 0 & 0 & 4 & 4.5 & & \\
\hline $\begin{array}{l}\text { Enterobacter spp. } \\
\text { Enterococcus }\end{array}$ & 7 & 10.3 & 1 & 5 & 8 & 9.1 & 0.724 & 0.4691 \\
\hline spp. & 4 & 4.4 & 4 & 20 & 7 & 8 & 2.2647 & 0.0235 \\
\hline K.pneumoniae & 14 & 20.6 & 1 & 5 & 15 & 17 & 1.6297 & 0.1032 \\
\hline Klebsiella spp. & 4 & 5.9 & 4 & 20 & 8 & 9.1 & 1.9306 & 0.0535 \\
\hline $\begin{array}{l}\text { P.aeruginosa } \\
\text { Pseudomonas } \\
\text { spp. }\end{array}$ & 4 & 5.9 & 0 & 0 & 4 & 4.5 & & \\
\hline $\begin{array}{l}\text { S.aureus } \\
\text { Staphylococcus }\end{array}$ & 1 & 1.5 & 0 & 0 & 1 & 1.1 & & \\
\hline $\begin{array}{l}\text { Streptococcus } \\
\text { spp. }\end{array}$ & 1 & 1.5 & 0 & 0 & 1 & 1.1 & & \\
\hline Sum & 2 & 2.9 & 1 & 5 & 3 & 3.4 & 0.3278 & 0.6556 \\
\hline
\end{tabular}

Table 3: Microorganisms isolated from blood cultures in pediatric patients and adults from HCM ICUs in 2017.

In the Adults ICU, the microorganisms Klebsiella spp. (23.1\%), Enterococcus spp. (21.2\%), Escherichia coli and Staphylococcus aureus $(11.5 \%)$ were prevalent in more than $10 \%$. With lower prevalence Pseudomonas aeruginosa and Stenotrophomona spp. with $1.9 \%$ each were observed.

Table 3 shows that of the 88 blood cultures performed, 19 (21.6\%) are gram-positive and 69 (78.4\%) gram-negative cocci. Of the grampositive bacteria the most prevalent was Staphylococcus aureus, while for gram-negative Klebsiella pneumoniae prevailed. There was a significant difference between the proportions of Enterococcus species of pediatric and adult patients $(\mathrm{p}=0.0235)$.

In urocultures, Enterococcus spp. and Escherichia coli were the most isolated with $29.4 \%$ and $14.7 \%$ respectively (Table 4 ).

According to Table 5, in isolated samples of pus, the most prevalent bacterium was Pseudomonas aeruginosa with $24.3 \%$. In adults only Enterobacter and Enterococcus species were identified. There was a significant difference between the proportion of Enterobacter spp. in adult and pediatric patients $(\mathrm{p}=0.0001)$. In isolates from the catheter tip, 3 samples of Staphylococcus aureus, 2 of Klebsiella spp., and 1 of Acinetobacter spp., Klebsiella pneumoniae and Pseudomonas spp. were recorded. In the isolated samples of sputum, the most prevalent bacterium was Klebsiella spp. (2), Pseudomonas spp., Klebsiella pneumoniae and Enterobacter spp. with only 1 sample.

\begin{tabular}{|l|l|l|l|l|l|l|l|l|}
\hline \multirow{2}{*}{$\begin{array}{l}\text { Microorganism } \\
\text { s }\end{array}$} & \multicolumn{7}{|c|}{ Type of ICU } \\
\cline { 2 - 9 } & Pediatrics & \multicolumn{2}{|l|}{ Adults } & \multicolumn{2}{l|}{ Sum } & \multicolumn{2}{l|}{ Z Teste } \\
\cline { 2 - 9 } & $\mathbf{n}$ & $\%$ & $\mathbf{n}$ & $\%$ & N & $\%$ & Z & $\begin{array}{l}\text { P. } \\
\text { value }\end{array}$ \\
\hline A.baumanni & 1 & 6.3 & 0 & 0 & 1 & 2.9 & & \\
\hline $\begin{array}{l}\text { Acinetobacter } \\
\text { spp. }\end{array}$ & 0 & 0 & 1 & 6.3 & 1 & 2.9 & & \\
\hline Citrobacter spp. & 1 & 6.3 & 0 & 0 & 1 & 2.9 & & \\
\hline E.coli & 1 & 6.3 & 4 & 25 & 5 & 14.7 & 1.3126 & 0.1893 \\
\hline $\begin{array}{l}\text { Enterobacter } \\
\text { spp. }\end{array}$ & 2 & 12.5 & 1 & 6.3 & 3 & 8.8 & 0.7126 & 0.4761 \\
\hline $\begin{array}{l}\text { Enterococcus } \\
\text { spp. }\end{array}$ & 4 & 25 & 6 & 37.5 & 10 & 29.4 & 0.5323 & 0.5945 \\
\hline K.pneumoniae & 2 & 12.5 & 1 & 6.3 & 3 & 8.8 & 0.7126 & 0.4761 \\
\hline Klebsiella spp. & 0 & 0 & 4 & 25 & 4 & 11.8 & & \\
\hline P.aeruginosa & 0 & 0 & 1 & 6.3 & 1 & 2.9 & & \\
\hline S.aureus & 3 & 18.8 & 0 & 0 & 3 & 8.8 & & \\
\hline $\begin{array}{l}\text { Staphylococcus } \\
\text { spp. }\end{array}$ & 2 & 12.5 & 0 & 0 & 2 & 5.9 & & \\
\hline Sum & 16 & 47.1 & 18 & 52.9 & 34 & 100 & & \\
\hline
\end{tabular}

Table 4: Microorganisms isolated in urine samples in pediatric patients and adults from the HCM ICUs in the year 2017.

\begin{tabular}{|c|c|c|c|c|c|c|c|c|}
\hline \multirow{3}{*}{$\begin{array}{c}\text { Microorganism } \\
\mathbf{s}\end{array}$} & \multicolumn{8}{|c|}{ Type of ICU } \\
\hline & \multicolumn{2}{|c|}{ Pediatrics } & \multicolumn{2}{|c|}{ Adults } & \multicolumn{2}{|c|}{ Sum } & \multicolumn{2}{|c|}{ Z Teste } \\
\hline & $\mathbf{n}$ & $\%$ & $\mathbf{n}$ & $\%$ & $\mathbf{N}$ & $\%$ & $\mathbf{z}$ & $\begin{array}{c}\mathrm{P}- \\
\text { value }\end{array}$ \\
\hline A.baumanni & 1 & 2.9 & 0 & 0 & 1 & 2.7 & & \\
\hline $\begin{array}{l}\text { Acinetobacter } \\
\text { spp. }\end{array}$ & 6 & 17.6 & 0 & 0 & 6 & 16.2 & & \\
\hline Citrobacter spp. & 1 & 2.9 & 0 & 0 & 1 & 2.7 & & \\
\hline E.coli & 1 & 2.9 & 0 & 0 & 1 & 2.7 & & \\
\hline $\begin{array}{l}\text { Enterobacter } \\
\text { spp. }\end{array}$ & 1 & 2.9 & 2 & 66.7 & 3 & 8.1 & 3.8763 & 0.0001 \\
\hline $\begin{array}{l}\text { Enterococcus } \\
\text { spp. }\end{array}$ & 0 & 0 & 1 & 33.3 & 1 & 2.7 & & \\
\hline K.pneumoniae & 3 & 8.8 & 0 & 0 & 3 & 8.1 & & \\
\hline Klebsiella spp. & 1 & 2.9 & 0 & 0 & 1 & 2.7 & & \\
\hline
\end{tabular}




\begin{tabular}{|l|c|c|c|c|c|c|c|c|}
\hline P.aeruginosa & 9 & 26.5 & 0 & 0 & 9 & 24.3 & & \\
\hline $\begin{array}{l}\text { Pseudomonas } \\
\text { spp. }\end{array}$ & 3 & 8.8 & 0 & 0 & 3 & 8.1 & & \\
\hline S.aureus & 6 & 17.6 & 0 & 0 & 6 & 16.2 & & \\
\hline $\begin{array}{l}\text { Staphylococcus } \\
\text { spp. }\end{array}$ & 1 & 2.9 & 0 & 0 & 1 & 2.7 & & \\
\hline $\begin{array}{l}\text { Stenotrophomon } \\
\text { a spp. }\end{array}$ & 1 & 2.9 & 0 & 0 & 1 & 2.7 & & \\
\hline Sum & 34 & 91.9 & 3 & 8.1 & 37 & 100 & & \\
\hline
\end{tabular}

Table 5: Microorganisms isolated in the samples of pus in pediatric patients and adults in HCM ICUs in the year 2017.

In CSF isolates, 2 strains of Streptococcus spp. and 1 of Staphylococcus aureus were recorded. In samples of pharyngeal exudate, 1 Escherichia Coli and 1 Klebsiella pneumoniae were identified. In the faeces samples only 1 Acinetobacter baumanni and 1 Acinetobacter spp. were recorded.

\section{Discussion}

Most of the bacteria identified in this study are of the Gramnegative genus with 79.3\% (142) against the Gram-positive 20.7\% (37) and fungal infections were not identified. A study on the prevalence and clinical outcomes of infections in Brazilian ICUs in 2012 found that gram-negative bacteria were more prevalent with a percentage of $72 \%$, corroborating with findings in this study [9]. This data shows that gram-negative bacteria are the most common cause of infections in ICUs in our hospital.

The most frequent bacterium was Staphylococcus aureus with 16.8\% (30), followed by Klebsiella pneumoniae with $13.4 \%$ (24), Enterococcus spp. with $10.1 \%$ (18), Klebsiella spp. with 9.5\% (17), Acinetobacter spp. with 8.9\% (16), Enterobacter spp. with 8.4\% (15), Pseudomonas aeruginosa 7.8\% (14), Escherichia coli 7.3\% (13), Acinectobater baumanni 4.5\% (8) and Pseudomonas spp. 3.9\% (7). A retrospective study conducted in Gabon on "Profile analysis of antimicrobial resistance" identified Staphylococcus aureus as the most common bacterium with $23.1 \%$, followed by Klebsiella pneumoniae with 22.3\% [10]. Barros et al. [11], in a similar study identified Pseudomonas aeruginosa as the most isolated bacteria followed by Staphylococcus Aureus. Another study conducted in sub-Saharan Africa and in low-income Asian countries on "antimicrobial susceptibility of bacterial isolates from community-acquired infections" identified the highest prevalence in Staphylococcus species [12].

About one-third of the population has Staphylococcus aureus as part of the transient flora of the skin constituting an important source of infection for the individual or for others and, is considered the main etiological agent of nosocomial and community infections [13].

In the present study, Staphylococcus aureus was more frequent in blood samples with a percentage of $57 \%$. Meneses et al. [14], in a study performed in the ICU of a General Hospital in Fortaleza identified Staphylococcus aureus as the most prevalent in blood cultures.

Pseudomonas aeruginosa was more prevalent in the Pediatrics ICU, mostly isolated in pus samples. Infections caused by this species of Pseudomonas usually are of hospital origin and in Brazil during the last four decades the incidence by Pseudomonas aeruginosa was responsible for $10 \%$ of all nosocomial infections [15]. According to Christopher et al. [16], the causes are associated with pneumonia due to chronic lung disease, mechanical ventilation longer than eight days, tracheotomy and previous use of antibiotics.

Escherichia coli was more frequent in patients from the Pediatrics ICU, mostly isolated in urine samples. This microorganism is described as the main cause of urinary tract infection and is the most common hospital infection in children, mainly females, due to the shorter length of the ureter compared to boys [17]. Rappelli et al. [18] E Mandomando et al. [19] identified $68.4 \%$ and $22.6 \%$ of strains of Escherichia coli in children under 7 years of age in faeces isolates.

Citrobacter spp. samples were identified in patients from the Pediatrics ICU, with a higher prevalence in blood samples. The results of these studies are differentiated by several studies related to Citrobacter species, where urine is described as the most isolated culture [20].

The species of Stenotrophomona were isolated in samples of urine, secretions and blood. In a similar study, species of Stenotrophomona were identified in blood isolates, catheter tips and pus [21].

\section{Conclusions}

The epidemiological surveillance, standard precautions, isolation measures, adequate materials and equipment, hygiene of the environment, training of the multi-professional team, implementation of control measures are important and determinant factors that may interfere in the results with a reduction in the prevalence rates of hospital infection.

\section{References}

1. WHO (2011) Report on the Burden of Endemic Health Care-Associated Infection Worldwide. Geneva, Switzerland.

2. Gonçalves TD, Puiatti MA, Perna DH, Martins NM, Marcos C, et al. (2015) Prevalence of hospital infection with the bacteria klebsiella in an Intensive Care Unit. Rev da Soc Bras Clínica Médica 13: 119-123.

3. Passoni RS, Mariano LR, Takahashi L da S, Erdmann M de F (2014) Prevalence of nosocomial infection in intensive care unit - a retrospective study. Rev da Enferm da UFSM 4: 410-418.

4. Nogueira PSF, Ferreira ER, Moura Costa MMF, Monteiro WMS, Brondi L (2009) Nosocomial infection profile at an University Hospital. Rev Enferm da UFSM 17: 96-101.

5. Warren D, Shukla S, Olsen M, Kollef MH, Hollenbeak CS, et al. (2003) Outcome and attributable cost of ventilator-associated pneumonia among intensive care unit patients in a suburban medical center. Crit Care Med 31: 1312-1317.

6. Vincent JL, Rello J, Marshall J, Silva E, Anzueto A, et al. (2009) International study of the prevalence and outcomes of infection in intensive care units. Am Med Assoc 302: 2323-2329.

7. Sandiumenge A, Lisboa T, Gomez F, Hernandez P, Canadell L, et al. (2011) Effect of antibiotic diversity on ventilator-associated pneumonia caused by ESKAPE Organisms. Chest 3: 643-651.

8. Monteiro LGS, Zimba TF, Sidat M (2015) Sensitivity of Enterobacteriaceae isolates from maputo central hospital, Mozambique 2009-10. Rev Cient UEM Sér Ciênc Bioméd Saúde Pública 1: 7-13.

9. Silva E, Junior LD, Da H, Fernandes S, Moreno R, et al. (2012) Prevalence and outcomes of infections in Brazilian ICUs: a subanalysis of EPIC II study. Rev Brazileira Ter Intensiva 24: 143-150.

10. Alabi AS, Frielinghaus L, Kaba H, Kosters K, Huson M, et al. (2013) Retrospective analysis of antimicrobial resistance and bacterial spectrum of infection in Gabon, Central Africa. BMC Infect Dis 13: 2-7. 
Citation: Mahaluça FA, Essack S, Sacarlal J (2018) The Etiology of Hospital Infections in the Intensive Care Unit of a Reference Hospital in Southern Mozambique. Clin Microbiol 7: 319. doi:10.4172/2327-5073.1000319

Page 5 of 5

11. Barros LM, Bento JN de C, Caetano JÁ, Moreira RAN, Pereira FGF, et al. (2012) Prevalência de micro-organismo e sensibilidade antimicrobiana de infecções hospitalares em unidade de terapia intensiva de hospital público no Brasil. J Basic Appl Pharm Sci 33: 429-435.

12. Ashley EA, Lubell Y, White NJ, Turner P (2011) Antimicrobial susceptibility of bacterial isolates from community acquired infections in Sub-Saharan Africa and Asian low and middle income countries. Trop Med Int Heal 16: 1167-1179.

13. Sales LM, Silva TM da (2012) Staphylococcus aureus meticilina resistente A challenge for public health. Acta Biomed Bras 3: 1-13.

14. Menezes EA, Sá KM, Cunha FA, Ângelo MRF, Oliveira IRN, et al. (2007) Frequency and susceptibility percentile of bacteria isolated in patients assisted in the Intensive Care Unit of the General Hospital of Fortaleza. J Bras Patol e Med Lab 43: 149-155.

15. Alves LNS, Oliveira CR de, Silva LAP da, Gervásio SMD, Alves SR, et al. (2012) Blood cultures: study of prevalence of microorganisms profile and sensitivity of antibiotics used in Intensive Care Unit. J Heal Sci Inst 30: 44-47.

16. Christopher A, Mshana SE, Kidenya BR, Hokororo A, Morona D (2013) Bacteremia and resistant gram-negative pathogens among under-fives in Tanzania. Ital J Pediatr 39: 1-8.
17. Soares LA, Nishi CYM, Wagner HL (2006) Isolation of bacteria causing urinary tract infections and their antimicrobial resistance profile. Brazilian J Fam Community Med 2: 84-92.

18. Rappelli P, Folgosa E, Solinas ML, Dacosta JL, Pisanu C, et al. (2005) Pathogenic enteric Escherichia coli in children with and without diarrhea in Maputo, Mozambique. FEMS Immunol Med Microbiol 43: 67-72.

19. Mandomando IM, Macete EV, Ruiz J, Sanz S, Abacassamo F, et al. (2007) Etiology of diarrhea in children younger than 5 years of age admitted in a rural hospital of southern Mozambique. Am Soc Trop Med Hyg 76: 522-527.

20. Badger J, Stins M, Kim KS (1999) Citrobacter freundii invades and replicates in human brain microvascular endothelial cells. Infect Immun 67: 4208-4215.

21. Rodrigues L, Gioia TS Di, Rossi F (2011) Stenotrophomonas maltophilia: emergent resistance to SMX-TMP in Brazilian isolates. A reality? J Bras Patol e Med Lab 47: 511-517. 